\title{
Variation of Extracellular Polymeric Substances (EPS) of Chlamydomonas reinhardtii under arsenic stress
}

\author{
C.H. Li ${ }^{1}$, J.Y. Zhang ${ }^{1}$, Q.N. Yu ${ }^{1}$, B.B. Dong ${ }^{1}$, C.H. Zhang ${ }^{2}$ \& Y. Ge ${ }^{2}$ \\ ${ }^{1}$ College of Resources and Environmental Sciences, Jiangsu Provincial Key Laboratory of Marine Biology, \\ Nanjing Agricultural University, Nanjing, P.R. China \\ ${ }^{2}$ Demonstration Laboratory of Elements and Life Science Research, Laboratory Centre of Life Science, \\ Nanjing Agricultural University, Nanjing, P.R. China
}

\begin{abstract}
Extracellular Polymeric Substances (EPS) are an important component of microorganisms. In this paper, we first compared the effectiveness of EPS extraction methods for amodel green algae (Chlamydomonas reinhardtii), and then investigated variations of EPS under arsenic (As) stress. Components of the algal EPS with or without arsenite and arsenate treatments were analyzed. The results showed that the different EPS extraction methods ranked as follows: $\mathrm{NaOH}>$ heating $>$ cation exchange resin $>$ EDTA $>$ centrifugation. However, $\mathrm{NaOH}$ extraction caused more cell disruption than the heating approach. The optimal extraction was heating at $50^{\circ} \mathrm{C}$, under which the amount of EPS was $40.06 \pm 0.297 \mathrm{mg} \mathrm{g}^{-1}$. Under $20 \mu \mathrm{g} \mathrm{L}^{-1} \mathrm{As}(\mathrm{V})$ and $200 \mu \mathrm{g} \mathrm{L}^{-1} \mathrm{As}(\mathrm{III})$, the amounts of EPS were $41.35 \mathrm{mg} \mathrm{g}^{-1}$ and $38.63 \mathrm{mg} \mathrm{g}^{-1}$ respectively, compared to control $\left(46.4 \mathrm{mg} \mathrm{g}^{-1}\right)$, indicating that the EPS production of C. reinhardtii was not affected by As.
\end{abstract}

\section{INTRODUCTION}

Extracellular polymeric substances (EPS) are the products with a high molecular weight, and they usually secreted by microorganisms (such as algae). The EPS typically are composed of polysaccharides, proteins and nucleic acids. Additionally, as a crucial substance adhesion to cell surface, EPS has a variety of biological roles on algal cells due to its abundant functional groups (e.g., $-\mathrm{COOH},-\mathrm{NH}$ etc.). EPS forms an important extracellular protective barrier on the algae cell surface, which can prevent toxicants. Moreover, those toxicants (e.g., $\mathrm{Pb}^{2+}, \mathrm{Cd}^{2+}$ ) also affect the production and composition of EPS. Research have shown that some microalgae has a strong ability to adsorb As and have the potential in removing the As pollution from water. However, the relation between microalgal EPS and As was not clear. Therefore, the objectives of this study were: (1) to establish a suitable method for the extraction and analysis of extracellular polymers substances (EPS) from C. reinhardtii, and (2) to quantify andanalyze the algal EPS under various As treatments.

\section{METHODS AND MATERIALS}

\subsection{Cultivation of algae and EPS extraction}

The green alga $C$. reinhardtii in this study was purchased from the Institute of Hydrobiology, Chinese Academy of Sciences. EPS was extracted by the following methods: centrifugation, heating, $\mathrm{NaOH}$, EDTA, CER treatments, respectively.

\subsection{Effect of arsenic on EPS compositions and content}

Upon exposure to different $\mathrm{As}(\mathrm{V})$ and $\mathrm{As}(\mathrm{III})$ concentrations, EPS from algae cultures was extracted using heating method. Proteins in EPS extract were determined by the modified Bradford method. The polysaccharides content in EPS was measured using the phenol-sulfuric method. Nucleic acids were determined by the diphenylamine colorimetric method.

\section{RESULTS AND DISCUSSION}

\subsection{Comparison of EPS extraction methods}

Table 1 showed that the amounts of EPS ranked as follows: $\mathrm{NaOH}>$ heating > cation exchange resin $>$ EDTA $>$ centrifugation. When $\mathrm{NaOH}\left(0.05 \mathrm{~mol} \mathrm{~L}^{-1}\right)$ was used, the amount of EPS reached $70.42 \mathrm{mg} \mathrm{g}^{-1}$. However, this method caused higher cell disruption (DNA $0.94 \mathrm{mg} \mathrm{g}^{-1}$ ) than others (Table 1). When the heating temperature was $50^{\circ} \mathrm{C}$, the amount of EPS was $40.06 \pm 0.30 \mathrm{mg} \mathrm{g}^{-1}$. Thus, heating method was chosen for EPS extraction from $C$. reinhardtii.

\subsection{Variations of EPS contents and compositions under arsenic stress}

The amount of EPS by the microalgae under the stress of different concentrations of $\mathrm{As}(\mathrm{V})$ in the 4-d cultivation are shown in Figure 1. When $C$. reinhardtii was inoculated in TAP media with 20, 100, 200, $500 \mathrm{mg} \mathrm{L}^{-1}$ of $\mathrm{As}(\mathrm{V})$, the EPS production at the 4-d 
Table 1. Contents of EPS components measured by different extraction methods.

\begin{tabular}{|c|c|c|c|c|}
\hline \multirow{2}{*}{$\begin{array}{l}\text { Extraction } \\
\text { method }\end{array}$} & \multicolumn{3}{|c|}{ Yield of EPS (mg.g $\left.{ }^{-1} \mathrm{DW}\right)$} & \multirow[b]{2}{*}{ DNA (\%) } \\
\hline & polysaccharide & protein & DNA & \\
\hline Centrifugation & $0.53 \pm 0.04 d$ & ND & ND & ND \\
\hline Heating & $25.48 \pm 0.21 b$ & $14.02 \pm 0.4 b$ & $0.56 \pm 0.03 b$ & $1.41 \pm 0.071 b$ \\
\hline $\mathrm{NaOH}$ & $28.71 \pm 1.24 \mathrm{a}$ & $40.77 \pm 0.18 \mathrm{a}$ & $0.94 \pm 0.12 \mathrm{a}$ & $1.36 \pm 0.202 b$ \\
\hline EDTA & $13.74 \pm 1.38 \mathrm{c}$ & $1.26 \pm 0.09 \mathrm{~d}$ & $0.38 \pm 0.04 c$ & $2.35 \pm 0.353 a$ \\
\hline CER & $27.88 \pm 5.16 \mathrm{a}$ & $7.21 \pm 0.14 \mathrm{c}$ & ND & ND \\
\hline
\end{tabular}

Note: Data in table are means \pm standard deviations. Different letters indicate significant difference between different extraction methods $(\mathrm{P}<0.05)$. ND means not detected or below the detection limit. Data are means \pm SD $(n=3)$.

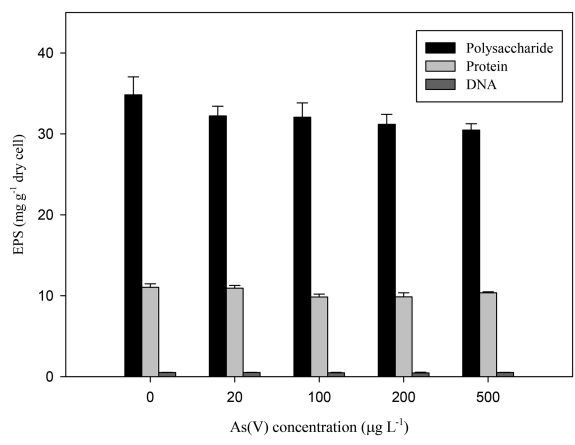

Figure 1. Variations in EPS from C. reinhardtii after exposure to different concentrations of $\mathrm{As}(\mathrm{V})$. Data are means $\pm S D(n=3)$.

decreased to $\sim 43.7,42.37,41.54,41.35\left(\mathrm{mg} \mathrm{g}^{-1}\right.$ dry cell), respectively, compared to the cultures in the TAP media without arsenate (the control).

The total amount of EPS of $C$. reinhardtii decreased from $46.4 \mathrm{mg} \mathrm{g}^{-1}$ (control) to $38.63 \mathrm{mg} \mathrm{g}^{-1}$ with $200 \mu \mathrm{g} \mathrm{L}^{-1}$ As (III) (Fig. 2). In this case, the protein of EPSsignificantly reduced by $45.72 \%$ (Fig. 2), which was much more than that with $20 \mu \mathrm{g} \mathrm{L}^{-1} \mathrm{As}(\mathrm{V})$.

The interaction of EPS with As has been suggested to decrease As toxicity to microorganisms. For example, Rhizobium strain VBCK1062 isolated from Vigna radiata plants showed an increase in EPS production when exposed to $5 \mathrm{mM} \mathrm{As}(\mathrm{V})$, however, there was a decline with concentration of $\mathrm{As}(\mathrm{V})$ higher than $5 \mathrm{mM}$ (Deepika et al. 2016). On the contrary, the present study showed that EPS was decreased upon various As treatments, suggesting that the relationship between EPS and As is complicatedand needs further investigations.

\section{CONCLUSIONS}

1) Heating method $\left(50^{\circ} \mathrm{C}, 3 \mathrm{~h}\right)$ was considered as the suitable EPS extraction method with high extraction efficiency $\left(40.06 \mathrm{mg} \mathrm{g}^{-1}\right)$, simple process and little cell disruption.

2) The amount of EPS production slightly decreased $5.82-11.53 \%$ when exposed to various arsenate

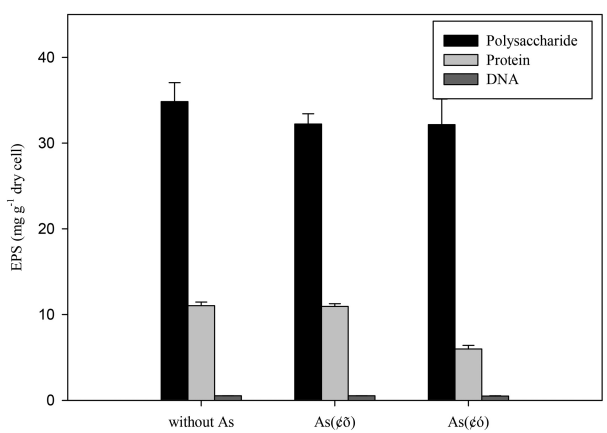

Figure 2. Variations of EPS from C. reinhardtii after exposure to arsenate $\left(20 \mu \mathrm{g} \mathrm{L}^{-1}\right)$ and arsenite $\left(200 \mu \mathrm{g} \mathrm{L}^{-1}\right)$. Data are means $\pm \operatorname{SD}(\mathrm{n}=3)$.

and arsenite treatments, suggesting that EPS and As interactions are complex and more studies are needed.

\section{ACKNOWLEDGEMENTS}

Financial support from Natural Science Foundation of China (31770548) is greatly appreciated.

\section{REFERENCES}

Dai, Y.F., Xiao, Y., Zhang, E.H., Liu, L.D. \& Qiu, L. 2016. Effective methods for extracting extracellular polymeric substances from Shewanella oneidensis MR-1. Water Sci. Technol. 74(12): 2987-2996.

Deepika, K.V., Raghuram, M., Kariali, E. \& Bramhachari, PV. 2016. Biological responses of symbiotic Rhizobium radiobacter strain VBCK1062 to the arsenic contaminated rhizosphere soils of mung bean. Ecotox. Environ. Safe. 134: $1-10$.

Taylor, C., Matzke, M., Kroll, A., Read, D.S. \& Svendsen, C. 2016. Toxic interactions of different silver forms with freshwater green algae and cyanobacteria and their effects on mechanistic endpoints and the production of extracellular polymeric substances. Environ. Sci-Nano 3(2): 396-408.

Wang, Y., Wang, S., Xu, P., Liu, C. \& Liu, M. 2015. Review of arsenic speciation, toxicity and metabolism in microalgae. Rev. Environ. Sci. Bio. 14(3): 427-451. 